\title{
The Effect of Low Back Pain on Quality of Life and Anxiety Levels in Pregnant Women
}

\author{
Gebe Kadınlarda Bel Ağrısının Yaşam Kalitesi ve Anksiyete \\ Düzeylerine Etkisi
}

\author{
Semra EROGLU1 ${ }^{1}$, Gulsah KARATAS ${ }^{2}$
}

Correspondence Address

Yazışma Adresi

\section{Semra EROGLU}

Baskent University, Department of Gynecology and Obstetrics, Konya, Turkey

E-mail: drsemraeroglu@gmail.com

Received \Geliş tarihi : :06.07.2020 Accepted \Kabul tarihi : 31.07 .2020 Online published $\quad: 12.07 .2021$ Elektronik yaym tarihi

Cite this article as: Bu makaleye yapilacak atıf: Eroglu S, Gulsah Karatas G. The effect of low back pain on quality of life and anxiety levels in pregnant women. Akd Med J 2021; (7)2:212-219

Semra EROGLU ORCID ID: 0000-0002-9959-9433 Gulsah KARATAS ORCID ID: 0000-0003-2812-485X
'Baskent University, Department of Gynecology and Obstetrics, Konya, Turkey

${ }^{2}$ Karabuk University, Department of Physical Therapy and Rehabilitation, School of Medicine, Karabuk, Turkey

\begin{abstract}
Objective: Maternal low back pain is a potent risk factor for poor health quality. We aimed to investigate the prevalence and risk factors of Low back pain (LBP) and Pelvic girdle pain (PGP) during pregnancy, and their effects on quality of life.

Material and Methods: Between March and August 2018, a total 160 pregnant women, who applied to outpatient clinics of the departments of Gynecology and Physical Therapy Rehabilitation Clinic, were included in this prospective study. Demographic characteristics, obstetric history of the participants, and LBP and PGP status during and before pregnancy were recorded. Severity of pain, functional capacity, Quality of life (QoL), and anxiety depression status were assessed using visual analogue scale (VAS), Oswestry Disability Questionnaire (ODQ), World Health Organization Quality of Life Scale Short Form (WHOQOL-BREF), and Hospital Anxiety and Depression Scale (HADS), respectively.
\end{abstract}

Results: The prevalence of LBP and PGP were $73.4 \%$ and $28.12 \%$, respectively. Total ODQ and VAS were significantly high in groups with LBP or PGP $(p=0.000$ and $p=0.000$, respectively). Of the WHOQOL-BREF subheadings, 'the general health' and 'physical health' parameters were significantly lower in women with LBP, whereas the 'social relationship' parameter was significantly low in those with PGP $(\mathrm{p}=0.003, \mathrm{p}=0.002$, and $\mathrm{p}=0.049$, respectively). The increase in anxiety and depression scores was only associated with $\operatorname{LBP}(\mathrm{p}=0.019$ and $\mathrm{p}=0.006$, respectively).

Conclusion: LBP and PGP during pregnancy adversely affect QoL, leading to functional limitations, depression, and anxiety disorders.

Keywords: Anxiety, Low-back pain, Depression, Pregnancy, Visual analogue scale, Oswestry disability questionnaire

ÖZ

Amaç: Gebelikte bel ağrısı, kötü sağlık kalitesi için güçlü bir risk faktörüdür. Gebelikte bel ağrısı (GBA) ve Pelvik kuşak ağrısı (PKA) prevalansını, risk faktörlerini ve yaşam kalitesine etkilerini araştırmayı amaçladık.

Gereç ve Yöntemler: Mart ve Ağustos 2018 tarihleri arasında Kadın Hastalıkları ve Fizik Tedavi ve Rehabilitasyon Kliniği polikliniklerine başvuran 160 hamile kadın bu prospektif çalışmaya dahil edildi. Katılımcıların demografik özellikleri, obstetrik öyküleri ve gebelik sırasında ve öncesinde GBA ve PKA varlığı kaydedildi. Ağrının şiddeti, fonksiyonel kapasite, Yaşam Kalitesi (YK) ve anksiyete ve depresyon durumu görsel analog skala (VAS), Oswestry Engellilik Anketi (ODQ), Dünya Sağllk Örgütü Yaşam Kalitesi Ölçeği Kısa Formu (WHOQOL- BREF) ve Hastane Anksiyete ve Depresyon Ölçeği (HADS) sırasıyla uygulandı.

Bulgular: GBA ve PKA prevalansı sirasiyla \% 73.4 ve \% 28.12 idi. Toplam ODQ ve VAS, GBA veya PKA olan gruplarda anlaml olarak daha yüksekti (sırasıyla $p=0.000$ ve $p=0.000$ ). WHOQOL-BREF alt pozisyonlarından 'genel sağlık' ve 'fiziksel sağlık' parametreleri GBA'lı kadınlarda anlamlı olarak daha düşükken, 'sosyal ilişki' parametresi PKA'lı olanlarda anlamlı olarak daha düşüktü $(\mathrm{p}=0.003$, $\mathrm{p}=0.002$ ve $\mathrm{p}=0.049)$. Anksiyete ve depresyon skorlarındaki artış sadece GBA ile ilişkili bulunmuştur (sirasiyla $\mathrm{p}=0.019$ ve $\mathrm{p}=0.006$ ).

Sonuç: Gebelik sırasında GBA ve PKA, yaşam kalitesini olumsuz yönde etkiler ve fonksiyonel sinırlamalara, depresyona ve anksiyete bozukluklarına yol açar.

Anahtar Sözcükler: Anksiyete, Bel ağrısı, Depresyon, Gebelik, Görsel analog skala, Oswestry engellilik anketi 


\section{INTRODUGTION}

Low back pain (LBP) and pelvic girdle pain (PGP) are the most common musculoskeletal complaints during pregnancy and postpartum period (1). Although the main cause of these pains remains unknown, it is not due to a gynecological problem but caused by changes in the musculoskeletal system. In the general population, rheumatic diseases can cause back pain and hormonal changes can cause joint and back pain (2-4). In pregnancy, the center of gravity of pregnant women tends to move forward due to the growing uterus. In order to compensate and restore the center of gravity, a physiological increase in lordosis occurs. Hormonal changes cause edema and vascularization in the connective tissue and increase in mobility in the sacroiliac, sacrococcygeal, and pubic joints. This change helps maintaining a good posture for pregnant women. With the relaxation of the symphysis pubis, up to $1 \mathrm{~cm}$ widening occurs, which facilitates the descent of the baby at birth. In final, it ends up with PGP, LBP and numbness and weakness in the extremities (5). Although low back pain is used as a general term in pregnancy, it includes the concepts of LBP and PGP. Since the etiology and related factors of these pathologies are different from each other, it is necessary to distinguish these entities. PGP includes symphysis pubis dysfunction (SPD) and/or pain in the sacroiliac joint (PGP includes sacroiliac joint paint because of symphisis pubis disfunction (SPD) and/op diastasis). Studies have shown that LBP is more frequent than PGP and has a significant impact on quality of life (QoL) during pregnancy and postpartum period (6), with a prevalence ranging between $20-90 \%$ (6-10). The etiology is multifactorial and often due to hormonal, vascular, and biomechanical changes. In order to think that this is related to pregnancy, first of all, fibromyalgia and other muscle-joint diseases should be excluded (11). Risk factors include age, socioeconomic status, history of 'LBP' or 'LBP in previous pregnancy', parity, body mass index (BMI), family history, heavy work conditions, and history of hypermobility $(1,12)$. Ligament laxity increases due to hormonal effect in the first trimester; LBP and PGP may occur and increases as the gestational week progresses (13). Although they often recover after birth, it has been reported that $33 \%$ of women can still have pain within 12 weeks after birth (14). It is noteworthy that low back and hip pain that occurs during and after pregnancy negatively affects the QoL of pregnant women and caused an increase in anxiety and depression scores in a limited number of studies (10, 14-16). Moreover, despite the negative effects on maternal and fetal health as well as the adverse effects on social and psychological life, there are not enough studies in our country yet (15). The aim of this study was to investigate the prevalence of LBP in our region and its impact on QoL and anxiety scores, with the goal of providing preventive health services.

\section{MATERIAL AND METHODS}

From March 2018 through August 2018, a total of 160 volunteers from pregnant women with $1^{\text {st }}$ to $3^{\text {rd }}$ trimester, who applied to outpatient clinics of the departments of Obstetrics Gynecology and Physical Therapy and Rehabilitation in Karabük University Training and Research Hospital, were included. Pregnant women who defined a pain for at least 1 week in the lumbar region or pelvis were determined as the study group and the pregnant women without pain were selected as the control group. Patients with pain were evaluated by a physical medicine rehabilitation specialist. Patients were asked to show their painful areas with their hands. In clinical examination; lumbar spine range of motion, palpation of lumbar paraspinal muscles, muscle strength test of lower extremities, sensory and reflex examination, hip joint movements, and straight leg lift test were performed. Participants were included in the study group when clinical examination results were consistent with the reported data. Written informed consent was obtained from all participants. Exclusion criteria included receiving treatment for LBP (i.e., non-steroidal anti-inflammatory drugs), having psychiatric, orthopedic, or neurological disease, and history of spinal trauma, or slipped disc. This prospective study was approved by the Karabuk University Clinical Research Board, with the decision no: 3/7, on February 28, 2018.

The study was conducted according to the ethical standards stated in the 1964 Helsinki Declaration. In our study, research and publication ethics were complied with.

Age, height, weight, gravity, parity, abortion numbers, gestational week, weight gain were recorded. Body mass indexes (BMI) calculated as weight/height ${ }^{2}$.

Visual analog scale (VAS); on a 10-cm vertical graph, the patients marked the most appropriate range between "no pain (0)" and "most severe pain (10)". The point marked on the line was measured via a ruler and the pain intensity of the subjects was recorded in centimeters (cm). VAS score has been shown to be a valid and reliable tool that is also sensitive to pain and minor changes in pain intensity as a response to treatment (17).

Oswestry Disability Questionnaire (ODQ); the questions in the Turkish version were asked and answers were recorded (18). ODQ is designed to assess how back pain affects a person's ability of managing daily life, consisting of 10 questions such as personal care in daily activities and social life, lifting, and walking. Each question is scored on a 6 -point scale ( 0 to 5$)$; ' 0 ' indicates no limitation and ' 5 ' indicates the maximum limitation. The score is then added and interpreted as the severity of the perceived disability of the patient (the higher the score, the greater the disability). 
Hospital Anxiety and Depression Scale (HADS); the scale that determines the risk of anxiety and depression in patients with physical or psychiatric disorders (19). The questionnaire consists of 14 questions, seven of which measure the risk of anxiety and the other seven measures the risk of depression. Each question is scored between 0 and 3; above 10 points for anxiety and above 7 points for depression is considered at risk.

World Health Organization Quality of Life Scale Short Form (WHOQOL-BREF); it is prepared to evaluate how an individual perceives the QoL. The scale with closed-end questions includes four domains as follows; physical, social, environmental, and psychological. It is measured in four dimensions, with each scored between 0 and 100 points. An increase in total score means an improvement in QoL. Turkish validity and reliability study of the scale was developed by Eser et al. in 1999 and a national question was added to the scale during their studies, hence the number of questions was increased to 27 (20).

Statistical analysis; SPSS version 21.0 was used for all statistical analysis. Kolmogorov Smirnov test was used determine whether the data were normally distributed or not. Student's t test was used for comparison of the normally distributed data and Pearson correlation test was used for correlation. Mann Whitney U test was used for comparison of non-normally distributed data and Spearman test was used for correlation. Chi-square test was used to determine the relationship between categorical data. $P<0.05$ was considered as statistically significant.

\section{RESULTS}

A total of 160 pregnant women were included in the study. The mean age of the participants was $27.2 \pm 5.2$ and the mean gestational age was 25 weeks. In $42.5 \%(\mathrm{n}=79)$ of the women, it was the first pregnancy. About $57.5 \%$ (n = 81) had delivered at least one birth and $14.5 \%$ had an abortion history. All participants were married and 78\% were housewives $(\mathrm{n}=145)$. Considering the level of education; $3.1 \%(\mathrm{n}=5)$ were literate, $10.6 \%(\mathrm{n}=17)$ had primary education, $24.3 \%(\mathrm{n}=39)$ had secondary education, $32.5 \%$ $(\mathrm{n}=52)$ had high-school education, 29.3\% $(\mathrm{n}=47)$ had higher education (i.e., university). LBP was significantly higher in $3^{\text {rd }}$ trimester $(40.3 \%)(\mathrm{p}=0.007)$, followed by $2^{\text {nd }}$ $(30.6 \%)$, and $1^{\text {st }}$ trimester $(29 \%)$. LBP and PGP was present in $74.37 \%(n=119)$ and $28.1 \%(n=45)$ of the participants, respectively. Demographic information of the population is shown in Table I.

There was no significant difference between those with LBP and control groups in terms of age, BMI, and parity $(p=0.85, p=0.257$, and $p=0.242$, respectively). Weight gain during pregnancy was significantly higher in patients with LBP $(p=0.004)$. VAS score and ODQ were signifi- cantly higher in patients with $\operatorname{LBP}(\mathrm{p}=0.000$ and $\mathrm{p}=$ 0.000 , respectively). In WHOQOL-BREF scoring, general and physical health were significantly lower in patients with $\operatorname{LBP}(p=0.003$ and $p=0.002$, respectively). Anxiety and depression scores were significantly greater in patients with $\operatorname{LBP}(p=0.019$ and $p=0.006$, respectively). In patients with LBP, the history of LBP prior to pregnancy was $84.8 \%$ and this was statistically significant $(\mathrm{p}=0.006)$ (Table II).

There was no significant difference between women with PGP and control groups in terms of age, BMI, parity, and weight gain during pregnancy $(p=0.125, p=0.498, p=$ 0.916 , and $p=0.141$, respectively). The presence of PGP was significantly higher as the gestational week progressed $(p=0.009)$. VAS and ODQ scores were significantly greater in patients with PGP $(p=0.000$ and $p=0.009$, respectively) and WHOQOL-BREF-social relations score was significantly lower $(p=0.049)$. There was no significant relationship between PGP and anxiety depression scores $(\mathrm{p}$ $=0.152$ and $\mathrm{p}=0.479$, respectively) (Table III).

Presence of LBP before pregnancy was $44.7 \%$ in patients with hip pain during pregnancy compared to $18.2 \%$ in those without hip pain, with a statistically significant difference $(p=0.001)$. There was a significant negative correlation between depression score and general health, physical health, social relationship, psychological health, and environmental health of the patients (Table IV).

Table I: Demographic data of the study population.

\begin{tabular}{lc}
\hline Variables & N=160 \\
\hline Age $($ years $)$, mean \pm SD & $27.5 \pm 5.2$ \\
\hline Height $(\mathrm{cm})$, mean \pm SD & $161.08 \pm 5.6$ \\
\hline Weight $(\mathrm{kg})$, mean \pm SD & $67.5 \pm 10.4$ \\
\hline BMI $\left(\mathrm{kg} / \mathrm{m}^{2}\right)$, mean \pm SD & $26.02 \pm 7.2$ \\
\hline Gravida, median $(\min -\mathrm{max})$ & $1.9(1-3)$ \\
\hline Parity, median $(\min -\mathrm{max})$ & $0.8(0-4)$ \\
\hline No pain, $\mathrm{n}(\%)$ & $36(22.5)$ \\
\hline LBP, $\mathrm{n}(\%)$ & $119(74.3)$ \\
\hline PGP, $\mathrm{n}(\%)$ & $45(28.1)$ \\
\hline Occupation, $\mathrm{n}(\%)$ & $131(\% 81.8)$ \\
$\quad$ Housewife & $29(\% 18.2)$ \\
\hline
\end{tabular}

Time of onset of pain (weeks), n (min $\max )$

$25(10-32)$

\begin{tabular}{cc}
\hline Onset of pain, $\mathrm{n}(\%)$ & \\
$1^{\text {st }}$ trimester & $46(29)$ \\
$2^{\text {nd }}$ trimester & $49(30.6)$ \\
$3^{\text {rd }}$ trimester & $65(40.3)$ \\
\hline
\end{tabular}

BMI: Body mass index; LBP: Low back pain; PGP: Pelvic girdle pain. 
Table II: Determination of associated risk factors in pregnant women with LBP and control group.

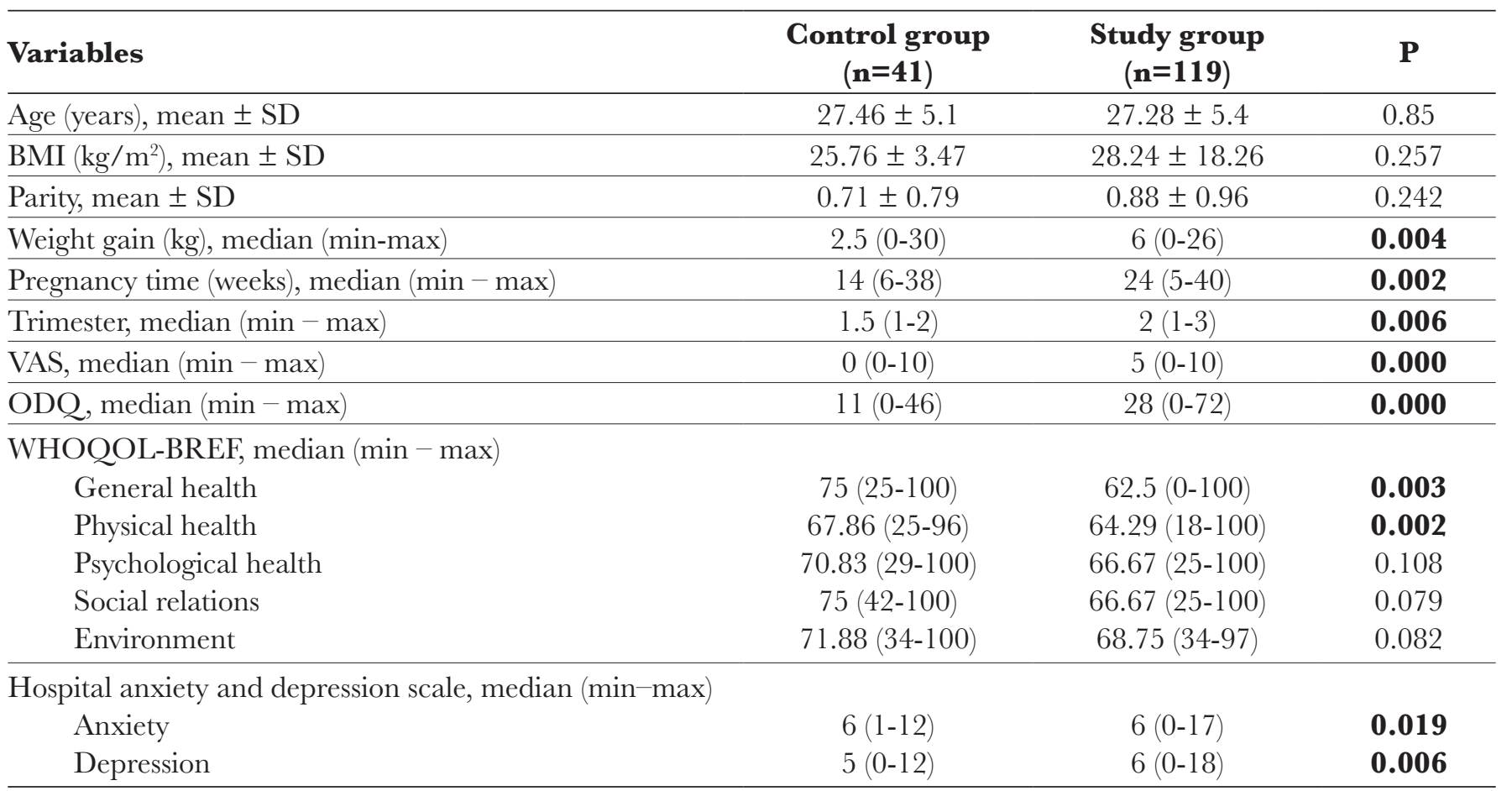

SD: Standard deviation; BMI: body mass index; VAS: visual analogue scale; ODQ: Oswestry disability questionnaire; WHOQOLBREF: The World Health Organization Quality of Life-BREF.

Table III: Determination of associated risk factors in pregnant women with PGP and control group.

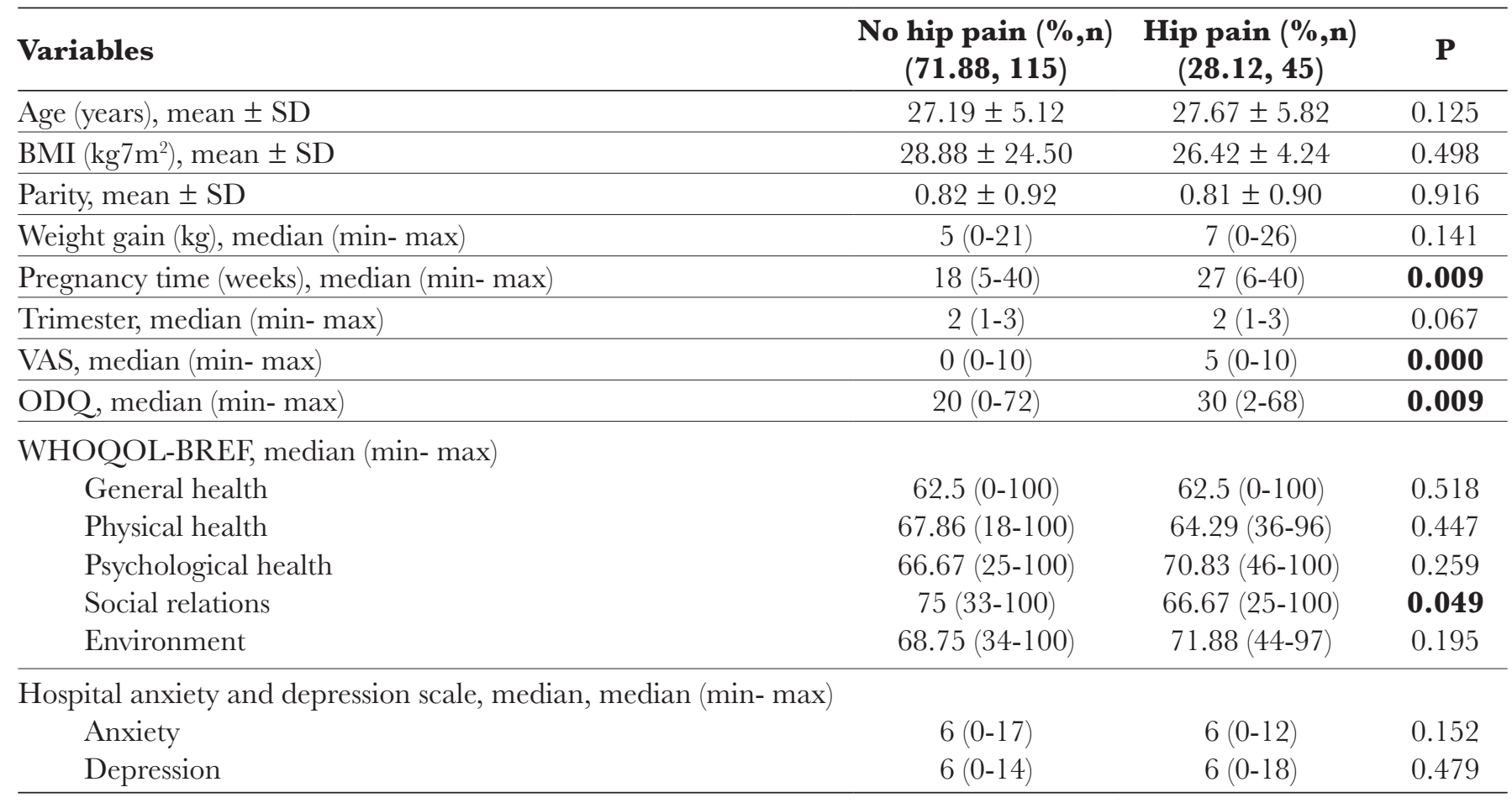

SD: Standard deviation; BMI: body mass index; VAS: visual analogue scale; ODQ: Oswestry disability questionnaire; WHOQOLBREF: The World Health Organization Quality of Life-BREF. 
Table IV: Correlations of anxiety depression scale with and Oswestry disability index and WHOQOL-BREF in pregnant women.

\begin{tabular}{lcc}
\hline \multirow{2}{*}{ Variables } & \multicolumn{2}{c}{ Anxiety depression scale } \\
\cline { 2 - 3 } & $\mathbf{R}$ & $\mathbf{P}$ \\
\hline ODQ total & 0.26 & $\mathbf{0 . 0 0}$ \\
\hline WHOQOL-BREF General health & -0.39 & $\mathbf{0 . 0 0}$ \\
\hline WHOQOL-BREF Physical health & -0.38 & $\mathbf{0 . 0 0}$ \\
\hline WHOQOL-BREF Social relationship & -0.42 & $\mathbf{0 . 0 0}$ \\
\hline WHOQOL-BREF Physiological health & -0.35 & $\mathbf{0 . 0 0}$ \\
\hline WHOQOL-BREF Environment & -0.31 & $\mathbf{0 . 0 0}$ \\
\hline
\end{tabular}

ODQ: Oswestry disability questionnaire; WHOQOL-BREF: The World Health Organization Quality of Life-BREF.

\section{DISGUSSION}

In this study, it was found that LBP in pregnant women was associated with limitation in functionality and increased anxiety and depression scores, having a correlation with VAS scores. Similarly, in pregnant women with PGP, although VAS and ODQ scores were significantly higher, we did not find any relationship with anxiety and depression scores. WHOQOL-BREF scores showed a significant decrease in 'general health' and 'physical health' in patients with LBP; whereas it showed significantly lower 'social relationship score' in patients with PGP. The prevalence of LBP and PGP in pregnant women was as high as $74.37 \%$ and $28.12 \%$, respectively. Although the prevalence of LBP varies in studies, it was reported $45-75 \%$ by Bishop et al., $72 \%$ by Mogren et al., and $53.9 \%$ by Sencan et al $(4,5,7)$. Ng et al. who designed a study and included only pregnant women working in office conditions in Malaysia found the prevalence of LBP as high as $84.6 \%(57.8 \% \mathrm{LPP}$ and $26.8 \%$ PGP), which was attributed to exhausting daily activities and inadequate education in maintaining a good posture (i.e., back posture) (9). It is thought that these variations across the studies may be related to the differences between the selected populations, the design of the study (retrospective vs. prospective), and the inability to determine the exact location of the pain (i.e., LBP? or hip pain? or PGP?).

In this study, we did not find any relationship between the age of patients and the presence of LBP or PGP. Many studies in the literature support this conclusion. Some publications demonstrated no association between age and pregnancy-associated lumbopelvic pain $(9,21)$. On the contrary, Ostgaard showed that LBP was more frequent in younger mothers than older counterparts (22). Different results in the literature were likely due to differences in the distribution and the size of sample or differences in genetic factors (23). As the gestational week progressed, both LBP and PGP were significantly higher in pregnant women.
Pain was most commonly observed in the $3^{\text {rd }}$ trimester. During pregnancy, LBP and groin pain usually starts at $18^{\text {th }}$ week and makes a peak between $24^{\text {th }}$ and $36^{\text {th }}$ weeks. The greater incidence of LBP in the $3^{\text {rd }}$ trimester may be associated with an increased load on the vertebrae due to increased pregnancy weight $(1,24)$. Similarly, Sencan reported that LBP was most frequent in the $3^{\text {rd }}$ trimester, whereas it was more frequent in the $2^{\text {nd }}$ trimester followed by $3^{\text {rd }}$ and $1^{\text {st }}$ trimesters $(47.2 \%)$ in the study by $\mathrm{Ng}(9-10)$. Different results may be determined due to differences in the distribution and size of samples. In our study, there was no correlation between parity and LBP or PGP. Conversely, in some studies, parity has been recognized as a risk factor for pregnancy associated-LBP $(8,25)$. We found that lumbopelvic pain was significantly higher in working mothers than housewives. Walking, sitting, and unsuitable postures were shown as the possible reasons for this situation. On the contrary, Kwanga et al. found LBP to be higher in housewives than working women, stating that this may be related to inappropriate posture during housework (9). In this study, there was a significant increase in LBP as weight gain increased during pregnancy, with no difference in PGP. Similarly, in the study including 1100 Iraqi pregnant women (26), while there was no relationship between BMI and LBP during pregnancy, some studies reported higher prevalence of pain in women with higher BMI (27). In a study of 639 pregnant women by Mogren et al., it was found that $\mathrm{BMI}$ values before pregnancy, at the end of pregnancy, and at $6^{\text {th }}$ month after birth were higher in women with lumbopelvic pain and the pain persisted after pregnancy (8). Since weight gain depends on the nutrient intake and physical activity, it is thought that lifestyle changes and proper weight gain may reduce LBP during and after pregnancy. In our study, LBP before pregnancy and history of lumbopelvic pain in previous pregnancy were found to be the most important risk factors. Studies support our results $(9,10)$. Repetitive nature of pain is an important risk factor to be considered in terms of affecting the QoL of patients 
in the future $(1,28)$. In $80-95 \%$ of cases, the pain regressed in the postpartum period; however, pain persists in $20 \%$ of the patients (29). The pain that also persists in postpartum period is $30 \%$ more susceptible to metabolic disorders and musculoskeletal diseases such as high BMI, osteoarthritis, and lumbopelvic pain. Considering the negative consequences of obesity today, counseling patients at risk may prevent future degenerative musculoskeletal diseases and social losses they may cause. In the light of our results, it was shown that LBP and PGP may occur during pregnancy and lead to functional limitation in pregnant women and it was associated with anxiety and depression. Similarly, Kwanga reported that total ODQ score was correlated with VAS score in both LBP and PGP (9). Arnow reported the rates of lumbopelvic back pain (LBPP) among 5000 patients to be $41 \%$ in patients with depression and $10 \%$ in those without depression (30). In the study by Virgara et al., it was found that the functional disability index index was lower in women who have LBP and greater anxiety and depression scale than women who have LBP but no anxiety or depression. In other words, it was thought that greater anxiety depression scores could increase LBP (15). Although it is not fully understood whether anxiety and depression triggers pain or vice versa, both appear to have a negative impact on QoL of pregnant women, particularly in the last trimester. In our study, in WHOQOL-BREF scoring, while 'general health' and 'physical health' were significantly lower in patients with LBP, 'social relations score' was significantly lower in those with PGP. LBP and PGP have been shown to negatively affect patients' daily activities, psychosocial status, sleep status, and QoL (31). It has been shown that sleep disorders due to LBP will negatively affect infant and mother during pregnancy and also increase the risk of postpartum depression, caesarean section, preeclampsia, and prolonged delivery in pregnant women (28). LBP has been shown to be the most important cause of diseased life in Norwegian pregnant women (32). Not only that, it has altered depression rates and perspective-on-life. Gutke et al. has associated the pain in $3^{\text {rd }}$ trimester with postpartum depression and decreased QoL (31). Present findings indicate that patients with high pain scores are at risk for postpartum depression, hence experi- encing inadequate breastfeeding and early discontinuation of breastfeeding (33). Furthermore, a worse cognitive and emotional development was observed in infants of mothers with postpartum depression (34). Consequently, as well as the increase in the medicine intake, it causes a profound impact on the country's economy with diseased-life and loss of workforce. In addition, anxiety and pain may result in premature birth, increased rates of cesarean, low-birth weight, and maternal and perinatal complications such as intrauterine growth retardation (IUGR) $(15,16)$.

As the number of participants in this study is limited, our results may not fully reflect the general population. In the future, there may be different results with larger patient data.

\section{GONGLUSION}

LBP and PGP are the most common musculoskeletal pathologies during pregnancy. We found that LBP and PGP during pregnancy may lead to functional limitations in pregnant women and are associated with high anxiety and depression scores, with a negative impact on QoL. High anxiety depression scores and LBP negatively affect QoL and lead to high functional disability. With the help of psychological and physical support provided for pregnant women by a multidisciplinary team during and after pregnancy, functional capacity of the patients can be increased and QoL can be improved.

Conflict of Interest: The authors declare that they have no competing interest.

Financial disclosure: None.

\section{Author roles:}

SE: Designing the study, collecting data, writing the article and reviewing the article

GK: Designing the study, working with statistics, reviewing the article

Ethics approvel: This study was approved by the Karabuk University Clinical Research Board, with the decision no: 3/7, on February 28, 2018. 


\section{REFERENGES}

1. Casagrande D, Gugala Z, Clark SM, Lindsey RW. Low back pain and pelvic girdle pain in pregnancy. J Am Acad Orthop Surg 2015; 23(9): 539-49.

2. Karatas G, Bal A, Yuceege M, Firat H, Gurcay E, Ardic S, Cakci FA. Evaluation of sleep quality in patients with ankylosing spondylitis and efficacy of anti- TNF-a therapy on sleep problems: A polisomnographic study. Int J Rheum Dis 2018; 21(6): 1263-69.

3. Eroglu S, Karatas G, Aziz V, Gursoy AF, Ozel S, Gulerman HC. Evaluation of bone mineral density and its associated factors in postpartum women. Taiwan J Obstet Gynecol 2016; 58(6): 801-804.

4. Karatas F, Sahin S, Babacan T, Akin S, Sever AR, Altundag K. Leg cramps associated with tamoxifen use--possible mechanism and treatment recommendations. J BUON 2016; 21(2): 520-20.

5. Vleeming A, Albert HB, Östgaard HC, Sturesson B, Stuge B. European guidelines for the diagnosis and treatment of pelvic girdle pain. Eur Spine J 2008; 17(6): 794-819.

6. Morino S, Ishihara M, Umezaki F, Hatanaka H, Iijima H, Yamashita M, Takahashi M. Low back pain and causative movements in pregnancy: a prospective cohort study. BMC Musculoskeletal Disor 2017; 18(1): 416.

7. Bishop A, Holden MA, Ogollah RO, Foster NE, Back Study Team. Current management of pregnancy-related low back pain: a national cross-sectional survey of UK physiotherapists. Physiotherapy 2016; 102(1): 78-85.

8. Mogren IM, Pohjanen AI. Low back pain and pelvic pain during pregnancy: prevalence and risk factors. Spine 2005; 30(8): 983-91.

9. Ng BK, Kipli M, Karim AKA, Shohaimi S, Ghani NAA, Lim PS. Back pain in pregnancy among office workers: risk factors and its impact on quality of life. Horm Mol Biol Clin Investig 2017; 32(3):/j/hmbci.2017.32.issue-3/ hmbci-2017-0037/hmbci-2017-0037.xml.

10. Sencan S, Ozcan-Eksi EE, Guce I, Guzel S, Erdem B. Pregnancy-related low back pain in women in Turkey: prevalence and risk factors. Ann Phys Rehabil Med 2018; 61(1): 33-37.

11. Zioni T, Buskila D, Aricha-Tamir B, Wiznitzer A, Sheiner E. Pregnancy outcome in patients with fibromyalgia syndrome. J Matern Fetal Neonatal Med 2011; 24(11): 132528.

12. Borg-Stein J, Dugan SA. Musculoskeletal disorders of pregnancy, delivery and postpartum. Phys Med Rehabil Clin N Am 2007; 18(3): 459-76.

13. Vermani E, Mittal R, Weeks A. Pelvic girdle pain and low back pain in pregnancy: a review. Pain Pract 2010; 10(1): 60-71.
14. Gutke A, Lundberg M, Östgaard HC, Öberg B. Impact of postpartum lumbopelvic pain on disability, pain intensity, health-related quality of life, activity level, kinesiophobia, and depressive symptoms. Eur Spine J 2011; 20(3): 44048.

15. Virgara R, Maher C, Van Kessel G. The comorbidity of low back pelvic pain and risk of depression and anxiety in pregnancy in primiparous women. BMC Pregnancy Childbirth 2018; 18(1): 288.

16. Grote NK, Bridge JA, Gavin AR, Melville JL, Iyengar S, Katon WJ. A meta-analysis of depression during pregnancy and the risk of preterm birth, low birth weight, and intrauterine growth restriction. Arch Gen Psychiatry 2010; 67(10): 1012-24.

17. Price DD, McGrath PA, Rafii A, Buckingham B. The validation of visual analogue scales as ratio scale measures for chronic and experimental pain. Pain 1983; 17(1): 45-56.

18. Yakut E, Düger T, Öksüz Ç, Yörükan S, Üreten K, Turan D, Yakut Y. Validation of the Turkish version of the Oswestry Disability Index for patients with low back pain. Spine 2004; 29(5): 581-85.

19. Zigmond AS, Snaith RP. The hospital anxiety and depression scale. Acta Psychiatrica Scandinavica 1983; 67(6): 361-70.

20. Eser E, Fidaner H, Fidaner C, Eser SY, Elbi H, Göker E. WHOQOL-100 ve WHOQOL-BREF'in psikometrik özellikleri. Psikiyatri Psikoloji Psikofarmakoloji (3P) Dergisi 1999; 7(Suppl 2): 23-40.

21. Mens JM, Huis YH, Pool-Goudzwaard A. Severity of signs and symptoms in lumbopelvic pain during pregnancy. Man Ther 2012; 17(2): 175-79.

22. Östgaard HC, Zetherström G, Roos-Hansson E. Back pain in relation to pregnancy: a 6 -year follow-up. Spine 1997; 22(24): 2945-50.

23. Liddle SD, Pennick V. Interventions for preventing and treating low-back and pelvic pain during pregnancy. Cochrane Database of Sys Rev 2015; (9):CD001139.

24. Robinson HS, Veierød MB, Mengshoel AM, Vøllestad NK. Pelvic girdle pain-associations between risk factors in early pregnancy and disability or pain intensity in late pregnancy: a prospective cohort study. BMC Musculoskelet Disord 2010; 11(1): 91.

25. Mota MJ, Cardoso M, Carvalho A, Marques A, Sá-Couto P, Demain S. Women's experiences of low back pain during pregnancy. J Back Musculoskelet Rehabil 2015; 28(2): 351-57.

26. Mohseni-Bandpei MA, Fakhri M, Ahmad-Shirvani M, Bagheri-Nessami M, Khalilian AR, Shayesteh-Azar M, Mohseni-Bandpei H. Low back pain in 1,100 Iranian pregnant women: prevalence and risk factors. Spine J 2009; 9(10): 95-801. 
27. Malmqvist S, Kjaermann I, Andersen K, Økland I, Brønnick K, Larsen JP. Prevalence of low back and pelvic pain during pregnancy in a Norwegian population. J Manipulative Physiol Ther 2012; 35(4): 272-78.

28. Chang HY, Yang YL, Jensen MP, Lee CN, Lai YH. The experience of and coping with lumbopelvic pain among pregnant women in Taiwan. Pain Med 2011; 12(6): 84653.

29. To WW, Wong MW. Persistence of back pain symptoms after pregnancy and bone mineral density changes as measured by quantitative ultrasound-a two year longitudinal follow up study. BMC Musculoskelet Disord 2011; 12(1): 55.

30. Arnow BA, Hunkeler EM, Blasey CM, Lee J, Constantino MJ, Fireman B, Hayward C. Comorbid depression, chronic pain, and disability in primary care. Psychosom Med 2006; 68(2): 262-68.
31. Gutke A, Olsson CB, Völlestad N, Öberg B, Wikmar LN, Robinson HS. Association between lumbopelvic pain, disability and sick leave during pregnancy-a comparison of three Scandinavian cohorts. J Rehabil Med 2014; 46(5): 468-74.

32. Sydsjö A, Sydsjö G, Kjessler B. Sick leave and social benefits during pregnancy-a Swedish-Norwegian comparison. Acta Obstet Gynecol Scand 1997; 76(8): 748-54.

33. Dennis GL, McQueen K. Does maternal postpartum depressive symptomatology influence infant feeding outcomes?. Acta Paediatr 2007; 96(4): 590-94.

34. Grace SL, Evindar A, Stewart DE. The effect of postpartum depression on child cognitive development and behavior: a review and critical analysis of the literature. Arch Womens Ment Health 2003; 6(4): 263-74. 